\title{
Dysfunctional Gaze and the Representation(s) of Women in Nuala Ní Chonchúir's “As I Look”
}

\author{
Máximo Aláez Corral ${ }^{1}$
}

\begin{abstract}
In this article I intend to analyse Nuala Ní Chonchúir's short story "As I Look," from her 2009 collection Nude, in relation to the concept of dysfunction, the representation of the nude female body, and the deconstruction of the conventional male gaze. My analysis will be backed up by a theoretical framework on objectification and will focus on dysfunction in the gaze and representation, and also in narration. I aim at highlighting dysfunction as an instrument to convey a new meaning around the visual/literary representation of women, a more positive and desirable connotation than the "functional" order of the visual norm.
\end{abstract}

Keywords: dysfunction, Ní Chonchúir, nude, male gaze.

\section{[es] La mirada disfuncional y la(s) representacion(es) de la mujer en "As I Look" de Nuala Ní Chonchúir}

Resumen. En este artículo me propongo analizar el relato de Nuala Ní Chonchúir "As I Look," de su colección de relatos Nude (2009), en relación con el concepto de disfunción, la representación del cuerpo femenino desnudo, y la deconstrucción de la mirada masculina convencional. Mi análisis estará respaldado por un marco teórico sobre la reificación del cuerpo, y se centrará en la aplicación de la disfunción a los ámbitos de la mirada, la representación, y finalmente la narración. Me propongo, con todo ello, resaltar la importancia del concepto de disfunción como herramienta eficaz en la generación de un nuevo significado para la representación visual/literaria de la mujer, un significado más positivo y deseable que el aportado por el carácter "funcional" de la norma visual.

Palabras clave: disfunción, Ní Chonchúir, desnudo, mirada masculina.

Contents. 1. Introduction. 2. Some Theoretical Guidelines. 3. "As I Look": Towards A Dysfunctional Space Of Representation. 4. Conclusion.

How to cite this article: Aláez Corral, M. (2019) Dysfunctional Gaze and the Representation(s) of Women in Nuala Ní Chonchúir's “As I Look”, in Complutense Journal of English Studies 27, 247-258.

\section{Introduction}

"As I Look" is a short story from Nude (2009), a collection by Irish writer Nuala Ní Chonchúir (also known as Nuala O'Connor) (Dublin, 1970). Virtually all the stories in the collection are related to the representation or the perception of the naked body

1 Departamento de Filología Inglesa, Francesa y Alemana, Universidad de Oviedo

ORCID: 0000-0002-1852-0556

E-mail: malacor.01@gmail.com 
in one way or another; however, whereas most other stories deal with this topic tangentially or secondarily, "As I Look" directly addresses (and questions) the conventions and stereotypes about objectification in visual culture. The fact that the author has placed the story around the middle point of the book also helps to view it as a sort of paradigm or condensation of the themes of gazing and representing visually the female body, and in this sense it works as a sort of thematic hinge to structure the stories preceding and following it.

This is a short short-story (barely four pages long) with a very simple plot. A woman - the first-person narrator of the story - goes to an art gallery with her partner (Cam) to put an experiment into practice: testing what happens when she behaves unexpectedly or performs provocative actions within the art space, and watching people's reactions to what she does or says. Another woman, Rodi (the organizer of the experiment, and Cam's and the narrator's friend) is also supposed to be nearby, though her presence is only mentioned towards the end of the story. The narrator stages her act (in this case, changing the position of a couple of surrealist paintings) in front of an anonymous male visitor (whom she refers to as "The Man"), who eventually plays her game and joins her in her misbehavior, even though he reacts in a puzzled and disconcerted way at first. As the narrator and The Man leave the gallery together, she catches a glimpse of Cam and Rodi, presumably flirting with one another, but the narration of what she is watching eventually fuses with brief descriptions of the artworks she gazes at on their way to the exit.

"As I Look" is a story about gazing at the world with agency; in other words, about looking instead of being looked at. 'To look' here refers not only to the perception of one's own surroundings but also to the creation of the meanings assigned to what is looked at according to such perception. The construction of the self- the naked body, in particular-becomes tightly linked to the specifity of the cultural perspective under which it takes place. As we will see, the way the characters look at the world that surrounds them in the story plays a crucial role in allowing for an open and non-normative interpretation of nudity. This interpretation surely owes a great deal to the fact that the author is a declared feminist, although she has also stated her own peculiarities in this respect: "I am a feminist, but a feminist who loves men. [...] I don't deliberately set out to show men in any terrible light, no more than I set out to show women in a bad way" (Morales Ladrón 2014: 135).

The representation of the naked body is a theme Ní Chonchúir had already explored in her former short-story collections, The Wind across the Grass (2004), and To the World of Men, Welcome (2005). In both of them we can already find several hints of the author's interest in nudity, and in both we can also track her earliest attempts at ekphrasis. ${ }^{2}$ In the case of the first collection we can find a couple of stories containing some snippets of descriptions of pictures. In "I, Paula," a story centred around the life of German painter Paula Modersohn-Becker, a Cezanne painting is briefly described; and in "Odalisque" we have some references to Edouard Manet's art, as seen through Victorine Meurent, his model for the well-known Olympia painting (also a painter herself). In To the World of Men, Welcome, several stories offer

\footnotetext{
Ekphrasis features even more prominently in other stories in Nude (e.g. "Roy Lichtenstein's Nudes in a Mirror: We Are not Fake!", or "Juno out of Yellow"). There is even a very short story ("Ekphrasis") which, as its title indicates, is entirely an exercise on the literary reading of pictures, in this case Le dejeuner sur l'herbe by Manet and Picasso's version of the same painting, together with the album cover of a pop band from the 80 s which is also based on Manet's picture.
} 
brief glimpses at a few works of art. "Well Met, Well Met" contains an interesting description of an unidentified version of The Three Graces, during the course of a visit to an art gallery, as well as of Pierre Bonnard's $\mathrm{Nu}$ dans le bain. "From Life" also has a brief reflection on Picasso's version of Manet's Le dejéuner sur l'herbe (prefiguring the longer reading that would later appear in "Ekphrasis"), and in "Loveday" we have a short impression of Renoir's Les parapluies.

It is with Nude, however, that the author can finally focus on the topic of ekphrasis and is able to expand on what it means to see/read/write about the naked body in context. In the case of "As I Look" she achieves this goal, as we will see in a moment, both by resorting to a lively, playful and fast-paced narration, and by reflecting on the ways we read the visual representations of the body. Ekphrasis is a term "generally used to refer to works of poetry and prose that talk about or incorporate visual works of art" (Sager 2008: 9). Literary descriptions of art abound in the world of literature - especially in poetry, with examples from writers as diverse as Sylvia Plath, Howard Nemerov or John Ashbery, amongst many others ${ }^{3}$ - , and some other authors, such as Robert Walser or John Berger, have also stood out for specifically dealing with this topic in some of their works. ${ }^{4}$

The importance of ekphrasis should not be overlooked in Ní Chonchúir's short text, for the story is as much about looking at works of art as it is about describing them. It is precisely through the ekphrastic nature of the story that the author finds a means to reveal the way the naked body is represented, specifically in relation to how it is looked at. It goes far beyond the goals of this paper to discuss the effects or the extent of the so-called 'male gaze' in the history of visual — or literary-representation; suffice it to say that Ní Chonchúir uses the male gaze and its peculiarities boldly, if ambiguously, to create an empowered female gaze that leads to what I will call a 'dysfunctional space of representation.' The male gaze was identified and defined in feminist and gender studies to refer to the way in which men represented and looked at the female body in visual culture and art. Theorists like Laura Mulvey (1999) and John Berger (1972) contributed greatly to establishing the limits and focus of this 'way of seeing' that invariably placed men as subjects and women as objects of representation. By means of the gaze, men found a useful tool to enforce a role of passive submission onto the gazed person (usually a female), thus creating a distance between the active gazer and the passive object of contemplation. Needless to say, this paradigm, perpetuated over centuries of art practice and visual culture, has contributed to validate and legitimize a discriminatory situation wherein the naked female is usually denied any voice or agency and remains an ornament, or a mere source of pleasure for a male watcher. In this respect, the normative equals the 'functional,' because it offers the most efficient means to attain the main goal: visual pleasure and satisfaction from watching a body that has been reduced to an object status.

In the ensuing discussion I will try to show how Ní Chonchúir's story can be taken as an example of the intent to deconstruct the normative and the 'natural' (and eventually the functional) in representation. To back up my thesis I will analyse

\footnotetext{
See Bilman (2013) for a detailed analysis of ekphrasis in poetry.

See, for example, John Berger's About Looking (1980) and Ways of Seeing (1972), or Robert Walser's Looking at Pictures (2015).
} 
those elements related to dysfunction in the text, in the fields of the gaze, the representation of the body, and narration itself.

\section{Some Theoretical Guidelines}

Before starting the analysis of the story, we may establish a theoretical framework to help us dissect the text. Our first step should perhaps be to try to define what 'dysfunction' is, and determine how this concept can be applied to "As I Look." Apart from its generic medical meaning ("malfunctioning, as of an organ or structure of the body"), in sociology this term refers to "a consequence of a social practice or behavior pattern that undermines the stability of a social system". 6 The "behavior pattern" that is at work in Ní Chonchúir's short story affects mainly the way the representation of the naked female body is perceived, but it also finds a mirror image in the narrator's voice, to the extent that her narration of the events themselves is also defined by instability. Obviously, 'dysfunctional' is not necessarily the opposite of 'normative.' As we will see later on, there are some instances in the text where the characters behave according to normative standards and yet the way they perceive the images — or the space — around them is not a stable/functional one.

If the functional norm for the gaze is male (as Laura Mulvey (1999: 837-838) and John Berger (1972: 47) stated in their respective essays), here we have a woman who both looks and acts autonomously, thereby creating a tear in the norm and a dysfunctional space of representation within the realm of the male gaze. As we will see in a moment, the main character in Ní Chonchuir's story is not 'gazed' by anybody; in turn, she 'looks' both at the paintings and also at a man who happens to be visiting the gallery, and who is simply named "The Man" before he becomes the subject of her experiment. The Man, however, is not objectified (not more than the female main character is, anyway). Even though he plays an instrumental role in the plot, he is far from being denied a voice or a personality.

Women are objectified in visual culture not only by divesting them of their own power to see, but also by imposing on them the conscience of being objects of the male gaze: "[G]irls and women are typically acculturated to internalize an observer's perspective as a primary view of their physical selves" (Friedrickson 2007: 173). John Berger had already discussed this split function of women in the construction of the gaze: "Men act and women appear. Men look at women. Women watch themselves being looked at" (1972: 47). Visual art plays a key role in the construction of this normative and 'functional' paradigm of women's conscience as 'to-be-lookedat' objects. As Friedrickson states, objectification derives, in part, from a "socially sanctioned right of all males to sexualize all females, regardless of age or status" (my emphasis) (2007: 174). I have emphasized the 'all' in Friedrickson's assertion because I would like to draw attention on the gaze as a means to ensure power. Even though Friedrickson's words may sound a bit too categorical, the fact that the male gaze has retained its strength as an objectifying tool (for both genders, but mostly for women) over the last decades should tell us about the systematic and efficient way

According to the definition provided in the online dictionary $<$ infoplease.com $>$.

According to the Random House Unabridged Dictionary. 
in which it is employed, in the most varied range of contexts. ${ }^{7}$ These objectifying mechanisms have certainly become subtler and harder to notice over the last few years, but they are far from having disappeared. It is the task of a trained eye, combined with a critical pattern of thought, to reveal the male gaze subtly disseminated, embedded or hidden within contemporary visual culture (mass media and publicity in particular, but also cinema, video and contemporary art).

Let us now try to analyse how Nuala Ní Chonchúir's narrative messes with these normative patterns around the gaze, perception and sexuality to produce a dysfunctional and displaced reading of the female body from a female perspective.

\section{3. “As I Look": Towards a Dysfunctional Space of Representation}

Because of its short extension, "As I Look" is a fine example of concentration and selection: plot and characterization are reduced to the minimum, and yet the reader gets enough to understand what is happening at the start, who does what, and how the story ends. Right from the start of the story the nameless female narrator (and main character) makes a remark on a culturally inherited difference between 'nude' and 'naked': "Naked means unprotected and bare, stripped or destitute. Nude means unclothed, or being without the usual coverings" (Ní Chonchúir 2009: 61). Although the storyline deviates from this initial reflection as the plot progresses, I think we should stop for a moment on this dichotomy and analyse the extent to which it affects visual representation. We usually look at female bodies - as depicted in visual works of art - from the safety of a supposedly neutral point of view: our position as watchers, external both to the representation and to the context of the gallery or museum, acts as a legitimizing tool for our gaze. We are not behaving in any immoral way or committing any crime because we are looking at 'objects' (both the work of art and the representation contained therein). The word 'nude,' as the narrator suspects, does indeed play a crucial role in validating and legitimizing the unclothed body: if it is 'nude,' the body, not the person, takes the spotlight and invariably becomes an object. If the person retains her/his personality and individuality, she/he will be "naked.' But 'naked,' unlike 'nude,' is a term that leads to moral issues, for to be naked in public may be socially (and legally) punished, and any onlooker may be considered an accomplice in the 'depraved' act of exposing one's own flesh.

Ní Chonchúir's deconstruction of normative representation in the story is deceitfully simple, in the sense that her writing can neither be said to be entirely feminine, feminist or female (in the sense established in Eagleton 2003: 220), even though the narrator is a heterosexual woman with an assumed female voice. Furthermore, any assumption on 'reality' as regards gender within the text usually clashes with a constant denial of that same assumption. For example, the author seems to play along the sexist game of objectification by denying the main female character a name. This assumption soon turns out to be misguided, for even though the character does not have a name, she does have a voice, and quite a strong one, as well as a rounded and rich personality. Is, in either case, naming women — as Mary Eagleton (154) seems

\footnotetext{
Not all studies on objectification, however, follow the strict feminist/psychoanalytical approach. See, for example, Griet Vandermassen's essay, where the author strays off Laura Mulvey's canonical theory and refutes it by highlighting Darwinist determinism as the factor that causes/explains the male objectifying gaze.
} 
to suggest — a feminist gesture in itself? More importantly, what is the equivalent in the visual arts to naming women? Clearly, the answer to the last question should not be 'to represent them' (nor their bodies) since the presence of a female image on its own does not make for a powered representation of a given woman (just as giving a woman a name does not mean the same as giving her a voice).

We may have, therefore, depictions of women, on the one hand, and depictions of femininity, on the other. Ní Chonchúir plays with both types of representation throughout her story without seemingly adopting any fixed stance about it (either feminist, patriarchal, normative or non-normative). Women are depicted through their visual features but also through literary narration. In the text we access the visual through the literary, and this is the fissure Ní Chonchúir takes advantage of, in her twisted deconstruction of the act of looking, in order to posit dysfunction as an alternative to the normative objectifying male gaze. Two paintings are mentioned in the text - Giorgo de Chirico's Uncertainty of the Poet (1913), and Man Ray's Pisces (1938) — and both of them were produced by male artists and depict objectified naked women. ${ }^{8}$ It must be noted that although the visual art included in the story is unambiguously male, the one who looks and enacts empowerment through the gaze is a woman, one that speaks for herself and narrates the world around her as she sees it-i.e. 'as she looks.'

A focal point in Ní Chonchúir's story is voyeurism and the sexualization of the gaze. According to Griselda Pollock, voyeurism "involves using sight as a sexual activity" (cited in Eagleton 2003: 181), and she adds: "the eye itself can become an eroticized if not a fully sexual organ" (2003: 181). The act of looking is an act of exercising power on that which is looked at. There are many examples of depictions and representations of women that gaze at the viewer throughout the history of art. The fact that they 'gaze,' nevertheless, does not mean that they may be entitled to any kind of power through the visual. First and foremost, they are looked at. This is their value within the representational space. They serve no other purpose but to act as objects. Their gaze on us onlookers only reaffirms our place as the subjects who hold power. In "As I Look" we find a few instances of voyeurism: in the beginning, in particular, the female narrator describes herself (and other women) in terms of visual qualities, but later on she relishes on the sensual attractiveness of the nude renderings of the body in the paintings, linking the erotic to food. However, the narrator usually steers away from the conventional static contemplation of the body by introducing other senses (smell, touch and taste) in her descriptions, thus breaking the monolithic visual function of objectification.

In Ní Chonchúir's story we have a woman whose first reflections on the naked female body, as I mentioned above, hint at a collusion with the conventional approach to the beauty canon: "I have friends (women) who have no boobs or hips, and they look as flat and boring as a Dutch landscape; I feel sorry for them" (2009: 61). Given the playful nature of the main character and of the narration itself, nonetheless, this could be interpreted as Ní Chonchúir setting a conventional stance about the female body as a starting point, only to mess with it later on and eventually deconstruct it towards the end of the story.

8 In de Chirico's picture we see a representation of a headless classical female torso without any limbs, placed next to a bunch of bananas; in Ray's picture a very stylized naked woman in an oblique pose is lying next to a fish the same size as the woman. 
In fact, the narrator does not deny the (instrumental) pleasure derived from contemplating the naked body (either for her own satisfaction or her partner's), but at the same time she manages to remain a subject as long as she does not allow her own body to be objectified. Even when she describes her own body she is the subject of her own gaze. This she achieves by retaining her conscience as a woman, her individuality and her voice throughout the text, thus working against functional objectification. Mary Ann Caws (1992: 385-386) explains a crucial difference between the gaze and the glance — rephrasing Norman Bryson's own ideas on the topic - , which may prove useful in discerning whether the narrator's way of looking is an objectifying one. Whereas the gaze, admittedly, implies invasion, penetration or fixation of the seen object, the 'glance' reveals a much more ambiguous and less invasive status of vision:

This gaze gone hard, this stare, tends toward a certain violence, a will to penetrate, to pierce, to fix in order to discover the permanent under the changing appearances [...]. The glance, on the contrary, creates an intermittence in vision, an attack, as if in music, which withdraws afterwards into the calm of the non-seeing (Caws 1992: 385).

The female main character/narrator describes herself as a "not pretty" woman who, nevertheless, is happy to have a conventionally female anatomy. We might be tempted to interpret that she is falling for the trap of the beauty canon and the role of women as objects for visual pleasure, but this description of her body is, as I view it, a chance for her to speak with her own voice and define her physical appearance according to her own perceptions:

I don't look especially beautiful with no clothes on; I have a wodgy belly and I'm not pretty, but because I'm tall and a tadge overweight, I have shape; I look like a woman. That makes me happier than you could know. It makes Cam happy toohe likes to ponder my curves. (Ní Chonchúir 2009: 61) [My emphasis]

The female main character also describes The Man, who does not seem to be objectified either: "I stand in front of Pisces and glance at the man beside me. He seems a perfect Art Experimentee: older, conservative, with maybe a renegade's heart pumping his blood" (Ní Chonchúir 2009: 62). Both The Man and the female main character remain nameless throughout the text, but somehow Ní Chonchúir manages to provide them with a presence stronger - in terms of 'humanity' - than the one assigned to the other two named characters (Cam and Rodi), who turn out to be little more than stereotypical empty props in the overall scenery.

Pushing her empowered attitude a step forward, Ní Chonchúir's narrator is not satisfied just with 'seeing,' but also wants to touch, alter and change the artistic experience, and bring a dynamic approach into the static realm of the male order. The narrator says: "I think this painting would look better over there, beside that one, don't you?", and then adds: "I'm going to put them together. See if I'm right" (Ní Chonchúir 2009: 63). The man's reaction is to stare in shock and disbelief at her, but we may wonder whether his shocked reaction springs from the act of vandalism that is about to happen, or from the fact that it is a woman (and not a man) who looks at the works of art and wants to transgress the boundaries of the gaze. This non-nor- 
mative intermission of the other senses into the gaze seems to echo Lynda Nead's reflection about seeing:

What happens $[\ldots]$ when the desire to see becomes the need to touch? [...] The detection of a critical blurring of the senses can be seen as a mark of instability in the relationship between the connoisseur and the image, a point at which the controlling force of metaphor and aesthetic vision breaks down. (1992: 59)

In other words, when seeing merges with the desire to touch the aesthetic functionality of the image is broken down, the imagined distance that saves the onlooker's gaze from the danger of revealing its fake condition vanishes, and the gazer is exposed on equal terms with the gazed.

Nead brings about another interesting point: "[A] claim that is made for women's body performances is that they subvert the male gaze and prevent the fetishization of the female body" (1992: 59). In Ní Chonchúir's story we have a couple of artworks that (supposedly) appeal to a male gaze - the paintings by Man Ray and De Chirico, to which we will turn again in a moment-, depicting naked female bodies (interpreted as 'nudes') and painted by men under the influence of a male gaze within a system of male rules. However, they also appeal to a 'non-male' gaze, the deviant gaze of a woman who actually puts up a performance in a gallery in which she demystifies the static normative way of looking at nude female representations.

I have already highlighted the importance of the gaze in the representation of femininity and in the imposition of submissive roles to women. Nead wraps up my argument by stating that "[w] hether it be the gaze of the medic who defines the body as healthy or diseased, or the connoisseur who defines it as beautiful or ugly, the female body is caught in a perpetual cycle of judgement and categorization" (1992: 68). Ní Chonchúir's narrator puts into practice 'another way' to look at female bodies, and by so doing she creates an alternative space for representation. In Nude, there are other interesting examples of this alternative way of seeing ("Unmothered," "Mademoiselle O'Murphy," "Juno out of Yellow" or "Jackson and Jerusalem" are some examples where the main characters 'look' at works of art in a non-normative way).

Through the narrator's actions, Ní Chonchúir hints at the illicit/illegal as a means to free representation from the hypocritical frames of the established visual norm or canon: the nameless woman performs a seemingly illicit act consisting on changing a couple of pictures in the sacred space of the gallery. However, the action itself both 'doing' and 'saying' something in an autonomous and empowered way) — turns illegality into a defining trait for the character. This is stressed by the remark of the male character who witnesses her action: "“Fuck,' says The Man, looking from Cam to me. 'Hey, you're not allowed to do this"” (Ní Chonchúir 2009: 63). The Man's first reaction is to defend the normative: a work of art should 'only' be enjoyed from the position of the watcher. The male character, however, changes his mind as the woman effectively carries out her plan of changing the position of the paintings, finally colluding with her non-normative actions: "AAmazing,' The Man says, turning to smile at me. 'You were right."' (2009: 64).

Far from following a metaphysical/melancholic reading of de Chirico's picture, the female character/narrator in Ní Chonchúir's story focuses directly on its sexual connotations in relation to the other female representation. In Man Ray's painting 
a heavily aestheticized female nude lies on an abstract space close to an unnaturally large fish (presumably a mackerel). Both fish and woman establish an indexical relationship rooted in wildness, basic instinct (by means of the link between food and sex) and untamed sexuality, although there is a figurative distance between them that cannot be obviated. The passive, contemplative and aestheticized nude contrasts vividly with the lively, dynamic and colourful fish, in a similar way to what de Chirico displayed in his painting: "it's all sensuality and food and phallic-ness" (Ní Chonchúir 2009: 64). As I mentioned earlier, the ekphrastic quality of the narration contributes to highlight the constructed nature of the gaze, simultaneously revealing the clash between the normative (functional) creation of a nude and the 'deviated' (dysfunctional) reading of that same representation. In spite of its rebellious reputation, Surrealist art still places the female nude within the beauty canon, and uses the representation of women as objects for (male) titillation. As the female character observes, it is the "mad combi of the bananas and the fish" (2009: 64) what disrupts the screen of representation and contributes to a new reading of the nude, but we must not forget that it has been the character's agency (by means of her moving the pictures together) that has created the dysfunctional reading of both images as one.

The story's narrator, in fact, plays with both images without denying nor affirming the sexism implicit in either Surrealist paintings. Instead, what she does is take a perverse detour lead by the surreal as it intrudes in the real. This intrusion challenges the validity and legitimacy of the real as the 'proper' means of representation. The female voice is the one that imposes its own legitimacy over the paintings and over the time/space continuum. The narrator's voice, in short, invades the space of representation and, in passing, blurs the tight functional distinction between nude and naked. What so far was just an 'artistic' representation - devoid of any purpose other than an aesthetic one-acquires now an irreverent role: to provide enjoyment (regarding both the bodily and the aesthetic experience) to the 'otherness,' the feminine, not the looked-at but the looking, not the voiceless but the voiced, not the passive but the active.

Let us conclude by briefly turning to the text again. The story starts with an uncompromising positioning of the narrator's voice: "The perverse nature of some of the art in here annoys me" (Ní Chonchúir 2009: 61). If we follow Roland Barthes assertion that "in all narrative imitation remains contingent" (1977: 123), we may describe a 'dysfunctional narration' as one where the imitative efforts of the narrator and the implied author ${ }^{9}$ produce no persuasive effects on the reader, hence the text as a whole suffers from a persistent suspicion of artifice. We might even contend that a failed mimesis comes from a non-normative, deviated approach to the representation of the real - an approach that both attacks and denies power as a means to perpetuate social and cultural conventions.

By the story's ending there is a shift in narration towards ambiguity and obscurity, verging on the absurd, a blurred state in which the character's dysfunctional acts, behaviour or words are no longer linked to the illicit. There is also a shift in the representational status quo confirmed by the male character's words: "Surrealism is all about the hidden self,' The Man whispers [...]. 'It's all about obsession"” (2009: 64).

$9 \quad$ In my usage of concepts like 'narrator,' 'implied author' and 'author' I follow Wayne C. Booth's terminology as was established in his work The Company We Keep: An Ethics of Fiction (1988). 
This becomes manifest as the story approaches its climax towards the end, precisely the point where the narrator's dysfunctional voice meets the character's dysfunctional gaze:

We pass a girl who drops a metallic stone on the floor; another girl flicking a yoyo; a girl wearing red velour pumps; a girl with a pink scarf tied around her waist. We pass Cam, his long front flush to Rodi's front; his hands tangled into her hair and his lips hovering over her head.

We make it to the front door before they see us, The Man and me, the faux Dali still in his fist. (Ní Conchúir 2009: 64)

The 'real' event — the description of the contents of a few paintings the woman and the man pass by as they head for the exit of the gallery - turns into a piece of 'surreal' narration. We can still understand the text 'as if' it was narrated from a normative or objective perspective, but the way in which the paragraph is written forces us to distrust both the real (normative) and the surreal (non-normative). More importantly, the images the man and the woman pass by (the painted female representations) are described as if they were living human beings: they are no longer paintings but people 'doing' things, on the same level of 'reality' as the two other characters (Cam and Rodi).

\section{Conclusion}

"As I Look" is a paradigmatic example of how a dysfunctional approach to the conventional (male) gaze can be fruitful and useful in the literary description of female representations with a non-discriminatory and non-objectifying perspective. When such an alternative description takes the nude/naked body as its leitmotif, the contradictions and double standards of a system that systematically objectifies the female body and deprives it of its own sexual experience or its own voice come to the fore.

By analyzing some crucial aspects in Nuala Ní Chonchúir's short story, I have focused on dysfunction affecting both visual and literary representations of the body. A dysfunctional interpretation of the gaze destabilizes some basic assumptions about how the way we look at people may or may not turn them into objects. Objectification plays a crucial role in the submission and control of those who are 'looked at' (in the world of visual representation, mostly women). Ní Chonchúir's story, by contrast, questions - not without an ironic tone- who is looking, who is looked at, who holds the power, and who is subjected to that power.

We must not forget, however, that the main character's disruptive actions and comments take place in a context (the art gallery) where artistic representations of the female body abound. The story focuses on surrealist art and offers ekphrastic readings of two paintings by Man Ray and Giorgio de Chirico. In spite of the purportedly transgressive quality of surrealism, the visual representations of females in either painting confirm their status as objects (nudes, rather than naked women), very much in line with the conventional way of looking at the female body found in other art periods and styles. This is where the 'dysfunctional space of representation' enters the stage: the crossroad where the male reading of the female body clashes with a female voice that takes claim of her own space in her own terms, and is bold 
enough to put on a performance that challenges the boundaries of what may or may not be considered licit in conventional patriarchal representation. Ní Chonchúir creates her character not from the perspective of an object of contemplation but from the perspective of a subject who 'looks' and who is in full command of her thoughts and actions.

Even though the story is deeply concerned with painting, the gaze and visual representation, "As I Look" is still a literary piece which can be stripped down to a basic narrative line. The dysfunctional way of looking spreads all over the narrative and 'contaminates' it (this being especially noticeable in the final paragraphs of the story, where the surreal content of the pictures in the gallery seems to extend to the way the story itself is narrated).

Visual representations of female bodies are usually intended to be experienced differently depending on whether they are 'nude' or 'naked,' and in such differentiation lies their functionality. In the story's space of representation, however, a woman without a name can look, think, talk and act without becoming an object and without objectifying what she sees. Ní Chonchúir's story reveals that the way we look and are looked at, if we read the visual from a dysfunctional point of view, not only blurs the borders between subject and object, but is also filled with diverse details regarding gender, forcing the power of the gaze to ultimately dissolve in its own relativity.

\section{References}

“dysfunction." Random House Unabridged Dictionary, Random House, 1997. Dictionary. infoplease.com, https://www.infoplease.com/dictionary/dysfunction. Accessed 27 April 2018.

Barthes, Roland (1977). Image-Music-Text. London: Fontana Press.

Berger, John (1972). Ways of Seeing. London: Penguin.

Berger, John (1980). About Looking. New York: Pantheon Books.

Bilman, Emily (2013). Modern Ekphrasis. Bern: Peter Lang.

Braudy, Leo and Marshall Cohen, eds. (1999). Film Theory and Criticism: Introductory Readings. Oxford: Oxford UP.

Broude, Norma and Mary Garrard, eds. (1992). The Expanding Discourse. Feminism and Art History. New York: Icon Editions.

Caws, Mary Ann (1992). Ladies Shot and Painted: Female Embodiment in Surrealist Art. In Broude, Norma and Mary Garrard, eds., 381-396.

Eagleton, Mary (2003). A Concise Companion to Feminist Theory. New Jersey: Blackwell.

Friedrickson, Barbara L. and Tomi-Ann Roberts (2007). Objectification Theory: Toward Understanding Women's Lived Experiences and Mental Health Risks. Psychology of Women Quarterly 21: 173-206.

Morales Ladrón, Marisol (2014). 'I write short-short stories while I am writing a novel.' Interview with Nuala Ní Chonchúir. Estudios Irlandeses 9: 128-136.

Mulvey, Laura (1999) [1975]. Visual Pleasure and Narrative Cinema. In Braudy, Leo and Marshall Cohen, eds., 833-844.

Nead, Lynda (1992). The Female Nude. New York: Routledge.

Ní Chonchúir, Nuala (2004). The Wind across the Grass. Galway: Arlen House.

Ní Chonchúir, Nuala (2005). To the World of Men, Welcome. Galway: Arlen House.

Ní Chonchúir, Nuala (2009). Nude, London: Salt Publishing. 
Sage Eidt, Laura (2008). Writing and Filming the Painting. Ekphrasis in Literature and Film. Amsterdam/New York: Rodopi.

Vandermassen, Griet (2010). Woman as Erotic Object in Mainstream Cinema: A Darwinian Inquiry into the Male Gaze. The Evolutionary Review 1(1): 69-75.

Walser, Robert (2015). Looking at Pictures. New York: New Directions. 